\title{
Fructo-oligosaccharide effects on serum cholesterol levels. An overview ${ }^{1}$
}

\author{
Graciana Teixeira Costa ${ }^{\mathrm{I}}$, Giselle Castro de Abreu ${ }^{\mathrm{II}}$, André Brito Bastos Guimarães ${ }^{\mathrm{II}}$, Paulo Roberto Leitão de Vasconcelos ${ }^{\mathrm{IV}}$, \\ Sergio Botelho Guimarães ${ }^{2}$
}

DOI: http://dx.doi.org/10.1590/S0102-865020150050000009

IAssistant Professor, Nutrition Division, Federal University of Amazon (UFAM), Brazil. Fellow PhD degree, Postgraduate Program in Surgery, Department of Surgery, Federal University of Ceara (UFC), Fortaleza-CE, Brazil. Conception and design of the study, acquisition and interpretation of data.

II Graduate student, Faculty of Medicine, UFC, Fortaleza-CE, Brazil. Acquisition of data.

IIIFellow Master degree, Postgraduate Program in Surgery, Department of Surgery, UFC, Fortaleza-CE, Brazil. Acquisition of data.

${ }^{\mathrm{IV}} \mathrm{PhD}$, Full Professor, Coordinator, Postgraduate Program in Surgery, Department of Surgery, UFC, Fortaleza-CE, Brazil. Critical revision.

${ }^{\mathrm{V}} \mathrm{PhD}$, Associate Professor, Department of Surgery, Head, Experimental Surgical Research Laboratory (LABCEX), UFC, Fortaleza-CE, Brazil. Critical revision, final approval of manuscript.

\section{ABSTRACT}

PURPOSE: To address the effects of fructooligosaccharides (FOS) intake on serum cholesterol levels.

METHODS: We performed a search for scientific articles in MEDLINE database from 1987 to 2014, using the following English keywords: fructooligosaccharides; fructooligosaccharides and cholesterol. A total of 493 articles were found. After careful selection and exclusion of duplicate articles 34 references were selected. Revised texts were divided into two topics: "FOS Metabolism" and "FOS effects on plasma cholesterol."

RESULTS: The use of a FOS diet prevented some lipid disorders and lowered fatty acid synthase activity in the liver in insulin-resistant rats. There was also reduction in weight and total cholesterol in beagle dogs on a calorie-restricted diet enriched with short-chain FOS. Another study found that $2 \mathrm{~g}$ FOS daily consumption increased significantly serum HDL cholesterol levels but did not ensure a significant reduction in levels of total cholesterol and triglycerides. Patients with mild hypercholesterolemia receiving short-chain FOS $10.6 \mathrm{~g}$ daily presented no statistically significant reduction in serum cholesterol levels. However, when FOS was offered to patients that changed their lifestyle, the reduction of LDL cholesterol and steatosis was higher.

CONCLUSIONS: Fructooligosaccharides intake may have a beneficial effect on lipid metabolism and regulation of serum cholesterol levels in individuals that change their lifestyle. FOS supplementation use in diets may therefore be a strategy for lowering cholesterol.

Key words: Oligosaccharides. Dietary Fiber. Cholesterol. Dyslipidemias. Review. 


\section{Introduction}

Fructooligosaccharides (FOS) are naturally occurring oligosaccharides consisted of glucose molecules and fructose joined by Beta 1,2 glycosidic linkages nondigestible at the brush border by enzymes of the small intestine, highly fermentable in the colon ${ }^{1}$. FOS passes intact through the upper digestive tract without being digested but is degraded in the colon by indigenous bacteria ${ }^{2}$. FOS can be found in many plant foods, such as bananas, onions, garlic, asparagus, wheat, rye, Jerusalem artichoke, and can also be produced enzymatically ${ }^{3}$. FOS act as prebiotics, defined as "food ingredients that affect the intestinal flora beneficially, by stimulating selectively the growth and / or activity of one or a limited number of bacteria in the colon"4. FOS digestive tolerance depends on the amount of FOS intake, on the presence of factors that reduce their osmotic load in the small intestine and on the degree of colonic microflora adjusting in the fermentation of these sugars ${ }^{5}$. The importance of the osmotic effect of these sugars is determined by the concentration of sugar which leaves the stomach and it obviously depends on the amount ingested, but also on factors that reduce the gastric emptying speed such as the energy, the meal content, the solid content and viscosity ${ }^{5}$. The fraction fermented in the large intestine provides 8.4 $\mathrm{kJ} / \mathrm{g}$; energy loss when a sugar is fermented is approximately $50 \%{ }^{5}$. Part of this is due to the formation of SCFA and growth of bacteria, which in turn releases part of the energy as heat ${ }^{6}$.

FOS recent use as a food ingredient has stimulated various researches on their effects on health, mainly concerning their bifidogenic nature ${ }^{1}$. Thus, their potentially beneficial actions have been discussed, in the prevention and control of increased health problems, particularly those associated with the metabolic syndrome ${ }^{7}$. Agheli et al. ${ }^{8}$ studied the chronic effects of a short-chain fructo-oligosaccharide (FOS)-containing diet on plasma lipids and the activity of fatty acid synthase (FAS) in insulin-resistant rats and concluded that the addition of short-chain FOS prevented some lipid disorders, lowered fatty acid synthase activity in the liver ${ }^{8}$. Moreover, data on the effects of FOS on plasma lipids in humans are still conflicting 9 .

The beneficial effects of FOS on glucose metabolism have been discussed in a previous review article ${ }^{10}$. The aim of this review was to determine the current scientific knowledge on FOS specific role on serum cholesterol levels.

\section{Methods}

Pubmed medical database was searched for FOS articles from 1987 to 2014 without language restrictions. The search was limited to the following strings "fructooligosaccharides" and "fructooligosaccharides and cholesterol". Of the 493 initial results, including duplicates, 34 articles were selected for review. Older articles presenting similar results described in more recent papers were excluded. Revised texts were divided into two topics: "FOS Metabolism" and "FOS effects on plasma cholesterol."

\section{FOS metabolism}

Prebiotics such as FOS contribute to hypocholesterolemia via two mechanisms: decreasing cholesterol absorption accompanied by enhanced cholesterol excretion via feces, and the production of short-chain fatty acids (SCFAs) upon selective fermentation by intestinal bacterial microflora ${ }^{5,11}$.

As FOS are not hydrolyzed by endogenous enzymes in the human small intestine. Upon reaching the cecum and intestinal colon they are fully metabolized by colonic microflora by means of fermentation, generating gases (carbon dioxide, hydrogen, methane) and reducing colonic $\mathrm{pH}$ by production of lactate and short-chain fatty acids (SCFA) such as acetate, propionate, methylmalonyl-CoA, succinyl CoA, and butyrate, which are rapidly absorbed by the colonic mucosa. The solubility of such oligosaccharides in water decreases the fecal content and increases the intestinal transit time $\mathrm{s}^{3,5,10,12-14}$.The fraction fermented in the large intestine provides $8.4 \mathrm{~kJ} / \mathrm{g}\left(\mathrm{kcal}^{2}\right)$; energy loss when a sugar is fermented is approximately $50 \%{ }^{11}$.Part of this is due to the formation of SCFA and growth of bacteria, which in turn releases part of the energy as heat ${ }^{6}$. The SCFA are rapidly absorbed from the lumen of the colon resulting in a lower concentration in the feces $^{12}$.

When FOS was added to the diet of young Western subjects the oligosaccharide was recovered in feces and the total concentration of short-chain fatty acids, the $\mathrm{pH}$ and the fecal weight did not change ${ }^{13}$. The researchers concluded that FOS are fully metabolized in the large intestine ${ }^{13}$.

Similar to indigestible fibers, soluble indigestible prebiotics have been postulated to increase the viscosity of the digestive tract and increase the thickness of the unstirred layer in the small intestine, and thus inhibiting the uptake of cholesterol ${ }^{14}$.

\section{FOS effects on plasma cholesterol}

The percentage of total cholesterol as high density lipoprotein cholesterol, was significantly higher with Konjacglucomannan (KGM) powder (Konjac root fiber) supplementation than with the other diets after 9 wk. Liver cholesterol concentration 
was $31-34 \%$ lower with KGM and propionate diets than with the unsupplemented diet ${ }^{15}$.

Kim and Shin $^{16}$. used hypercholesterolemic-induced Sprague-Dawley rats $(n=32)$ and found that the administration of inulin for 4-weeks decreased serum LDL-cholesterol and increased serum HDL-cholesterol levels $(p<0.05)$ compared to the control. Rats fed with inulin also showed higher excretions of fecal lipid and cholesterol compared to the control $(\mathrm{p}<0.05)$, mainly attributed to reduced cholesterol absorption ${ }^{16}$.

Long-term (16 week) administration of oligofructose decreased total serum cholesterol concentrations in rats, but did not influence either the absorption of dietary cholesterol or the excretion of cholesterol or bile acids in ileostomy subjects ${ }^{17}$.

When evaluating supplementation with shortchain FOS $10.6 \mathrm{~g}$ daily consumption in patients with mild hypercholesterolemia, there was no statistically significant reduction in serum cholesterol levels ${ }^{9}$. The same happened when there was this carbohydrate supplementation in patients with type 2 Mellitus Diabetes ${ }^{3}$.

Apparently, the type of FOS ingested has a different impact on the lipid metabolism in humans. As a matter of fact most studies have observed a reduction of plasma triglyceride and/or cholesterol in humans ${ }^{18-20}$ when longchain FOS, such as inulin were used. Nevertheless, another study showed opposite results. Pedersen et al. ${ }^{21}$ investigated the effect of a daily intake of $14 \mathrm{~g}$ inulin added to a low-fat spread on fasting blood lipids in sixty-four young healthy women in a randomized doubleblind crossover study involving two periods of four weeks and did not find any significant differences between the test periods in plasma. On the contrary, studies utilizing short-chain FOS, like Actilight ${ }^{\circledR}$, were not effective in improving lipid metabolism ${ }^{22-23}$.

A Chinese study showed no change in intestinal lipase activity with $2-4 \mathrm{~g} / \mathrm{kg}$ FOS supplementation in the diet of chickens ${ }^{24}$.

Nakamura et $a .^{25}$ studied the effects of dietary FOS and concluded that it suppresses high-fat diet-induced body fat accumulation and inhibits intestinal absorption of dietary fat in mice.

A randomized, double-blind, placebo-controlled study found that $2 \mathrm{~g}$ FOS daily consumption increased significantly serum HDL levels, although it has not shown significant reduction in levels of total cholesterol and triglycerides ${ }^{26}$.

Another study compared a randomized group of patients who, in addition to FOS supplementation had a change of lifestyle, with physical exercise practice and a balanced diet, with another group that only had changes in lifestyle. The result was that the reduction of LDL and steatosis was higher in the group that besides changing the lifestyle, made dietary FOS supplementation $^{27}$.

Rats on a FOS diet decreased abdominal fat and serum levels of total cholesterol ${ }^{28}$. There was also reduction in weight and total cholesterol in beagle dogs on a calorie-restricted diet enriched with short-chain FOS ${ }^{29}$. OS supplementation also reduced the accumulation of liver triglyceride in mice $^{30}$.

Delgado et al. ${ }^{31}$ reviewed the potential of yacon, a tuberous Andean plant that presents high content of fructooligosaccharides and inulin ${ }^{32-33}$, and concluded that the consumption of FOS and inulin improves the growth of bifidobacteria in the colon, enhances mineral absorption and gastrointestinal metabolism and plays a role in the regulation of serum cholesterol ${ }^{31}$.

Rajkumarl $^{34}$ studied the effects prebiotic FOS administration $(10 \mathrm{~g} / \mathrm{d})$ used alone or in a "symbiotic" blend of putative $L$ salivarius preparation and observed that the blend exhibited superior influence on serum lipid profiles for 6 weeks compared with FOS alone. HDL levels were lower than $40 \mathrm{mg} /$ $\mathrm{dL}$ among few participants from both experimental groups. Interestingly, the total cholesterol and LDL in the symbiotic group were found to be more reduced $(\mathrm{p}<.05)$, when compared to the end point values of the probiotic group ${ }^{34}$.

Merino-Aguilar et $a l .^{35}$ treated obese rats with FOS fraction extracted from Psacalium decompositum for 12 weeks and found decreased body weight, cholesterol, triglycerides, and significantly reduced cytokines IL- 6 , IFN- $\gamma, \mathrm{MCP}-1, \mathrm{IL}-1 \beta$ and VEGF levels $(\mathrm{p}<0.05)^{35}$.

\section{Conclusions}

Fructooligosaccharides intake may have a beneficial effect on lipid metabolism and regulation of serum cholesterol levels in individuals that change their lifestyle. FOS supplementation use in diets may therefore be a strategy for lowering cholesterol.

\section{References}

1. Moore N, Chao C, Yang LP, Storm H, Oliva-Hemker M, Saavedra JM. Effects of fructo-oligosaccharide-supplemented infant cereal: a double-blind, randomized trial. Br J Nutr. 2003 Sep;90(3):581-7. PMID: 13129464.

2. McIntyre A, Young GP, Taranto T, Gibson PR, Ward PB. Different fibers have different regional effects on luminal contents of rat colon. Gastroenterology. 1991 Nov;101(5):1274-81. PMID: 1657677.

3. Alles MS, De Roos NM, Bakx JC, De Lisdonk EV, Zock Pl, Hautvast JG. Consumption of fructooligosaccharides does not favorably affect blood glucose and serum lipid concentrations in patients with type 2 diabetes. Am J Clin Nutr. 1999 Jan;69(1):64-9. PMID: 9925124. 
4. Gibson GR, Roberfroid MB. Dietary modulation of the human colonic microbiota: introducing the concept of prebiotics. J Nutr. 1995 Jun;125(6):1401-12. PMID: 7782892.

5. Bornet FRJ. Undigestible sugars in food products. Am J Clin Nutr. 1994 Mar;59(3 Suppl):763S-9S PMID: 8116563.

6. van Es AJH. Commissie polyalcoholen de energetische waarde van suikeralcoholen. The Hague: Voedingsraad, 1987:1-17.

7. Anderson JW, Baird P, Davis RH Jr, Ferreri S, Knudtson M, Koraym A, Waters V, Williams CL. Health benefits of dietary fiber. Nutr Rev. 2009 Apr;67(4):188-205. doi: 10.1111/j.1753-4887.2009.00189.x.

8. Agheli N, Kabir M, Berni-Canani S, Petitjean E, Boussairi A, Luo J, Bornet F, Slama G, Rizkalla SW. Plasma lipids and fatty acid synthase activity are regulated by short-chain fructo-oligosaccharides in sucrose-fed insulin-resistant rats. J Nutr. 1998 Aug;128(8):1283-8. PMID: 9687545.

9. Giacco R, Clemente G, Luongo D, Lasorella G, Fiume I, Brouns F, Bornet F, Patti L, Cipriano P, Rivellese AA, Riccardi G. Effects of short-chain fructo-oligosaccharides on glucose and lipid metabolism in mild hypercholesterolaemic individuals. Clin Nutr. 2004 Jun;23(3):331-40. PMID: 15158296.

10. Costa GT, Guimarães SB, Sampaio HA. Fructo-oligosaccharide effects on blood glucose: an overview. Acta Cir Bras. 2012 Mar;27(3):279-82. doi: 10.1590/S0102-86502012000300013.

11. Arjmandi BH, Craig J, Nathani S, Reeves RD. Soluble dietary fiber and cholesterol influence in vivo hepatic and intestinal cholesterol biosynthesis in rats. J Nutr. 1992 Jul;122(7):1559-65. PMID: 1320116.

12. Cummings JH, Pomare EW, Branch WJ, Naylor CP, Macfarlane GT. Short chain fatty acids in human large intestine, portal, hepatic and venous blood. Gut. 1987 Oct;28(10):1221-7. PMID: 3678950.

13. Alles MS, Hautvast JG, Nagengast FM, Hartemink R, Van Laere KM, Jansen JB. Fate of fructo-oligosaccharides in the human intestine. Br J Nutr. 1996 Aug;76(2):211-21. PMID: 8813896.

14. Dikeman CL, Murphy MR, Fahey GC Jr. Dietary fibers affect viscosity of solutions and simulated human gastric and small intestinal digesta. J Nutr. 2006 Apr;136(4):913-9. PMID: 16549450.

15. Venter CS, Vorster HH, Van der Nest DG. Comparison between physiological effects of konjac-glucomannan and propionate in baboons fed "Western" diets. J Nutr. 1990 Sep;120(9):1046-53. PMID: 2168943.

16. Kim M, Shin HK. The water-soluble extract of chicory influences serum and liver lipid concentrations, cecal short-chain fatty acid concentrations and fecal lipid excretion in rats. J Nutr. 1998 Oct;128(10):1731-6. PMID: 9772143.

17. Roberfroid MB. Prebiotics and probiotics: are they functional foods? Am J Clin Nutr. 2000 Jun;71(6 Suppl):1682S-7S; discussion 1688S-90S. PMID: 10837317.

18. Brighenti F, Casiraghi MC, Canzi E, Ferrari A. Effect of consumption of a ready-to-eat breakfast cereal containing inulin on the intestinal milieu and blood lipids in healthy male volunteers. Eur J Clin Nutr. 1999 Sep;53(9):726-33. PMID: 10509770.

19. Jackson KG, Taylor GR, Clohessy AM, Williams CM. The effect of the daily intake of inulin on fasting lipid, insulin and glucose concentrations in middle-aged men and women. Br J Nutr. 1999 Jul;82(1):23-30. PMID: 10655953.

20. Letexier D, Diraison F, Beylot M. Addition of inulin to a moderately high-carbohydrate diet reduces hepatic lipogenesis and plasma triacylglycerol concentrations in humans. Am J Clin Nutr. 2003 Mar;77(3):559-64. PMID: 12600843.

21. Pedersen A, Sandström B, Van Amelsvoort JM. The effect of ingestion of inulin on blood lipids and gastrointestinal symptoms in healthy females. Br J Nutr. 1997 Aug;78(2):215-22. PMID: 9301412
22. Luo J, Rizkalla SW, Alamowitch C, Boussairi A, Blayo A, Barry JL, Laffitte A, Guyon F, Bornet FR, Slama G. Chronic consumption of short-chain fructooligosaccharides by healthy subjects decreased basal hepatic glucose production but had no effect on insulinstimulated glucose metabolism. Am J Clin Nutr. 1996 Jun;63(6):93945. PMID: 8644690.

23. Luo J, Van Yperselle M, Rizkalla SW, Rossi F, Bornet FR, Slama G. Chronic consumption of short-chain fructooligosaccharides does not affect basal hepatic glucose production or insulin resistance in type 2 diabetics. J Nutr. 2000. Jun;130(6):1572-7. PMID: 10827212

24. Xu ZR, Hu CH, Xia MS, Zhan XA, Wang MQ. Effects of dietary fructooligosaccharide on digestive enzyme activities, intestinal microflora and morphology of male broilers. Poult Sci. 2003 Jun;82(6):1030-6. PMID: 12817461.

25. Nakamura $Y$, Natsume M, Yasuda A, Ishizaka M, Kawahata K, Koga J. Fructooligosaccharides suppress high-fat diet-induced fat accumulation in C57BL/6J mice. Biofactors. 2011 Jun 14. doi: 10.1002/biof.147.

26. Moroti C, Souza Magri LF, de Rezende Costa M, Cavallini DC, Sivieri K. Effect of the consumption of a new symbiotic shake on glycemia and cholesterol levels in elderly people with type 2 diabetes mellitus. Lipids Health Dis. 2012 Feb 22;11:29. doi: 10.1186/1476511X-11-29.

27. Malaguarnera M, Vacante M, Antic T, Giordano M, Chisari G, Acquaviva R, Mastrojeni S, Malaguarnera G, Mistretta A, Li Volti G, Galvano F. Bifidobacterium longum with fructo-oligosaccharides in patients with non alcoholic steatohepatitis. Dig Dis Sci. 2012 Feb;57(2):545-53. doi: 10.1007/s10620-011-1887-4.

28. Phuwamongkolwiwat $P$, Suzuki $T$, Hira T, Hara $H$. Fructooligosaccharide augments benefits of quercetin-3-O- $\beta$ glucoside on insulin sensitivity and plasma total cholesterol with promotion of flavonoid absorption in sucrose-fed rats. Eur J Nutr. 2014;53(2):457-68. doi: 10.1007/s00394-013-0546-2.

29. Ricci R, Jeusette I, Godeau JM, Contiero B, Diez M. Effect of short-chain fructooligosaccharide-enriched energy-restricted diet on weight loss and serum haptoglobin concentration in Beagle dogs. Br J Nutr. 2011 Oct;106 Suppl 1:S120-3. doi: 10.1017/ S0007114511004107.

30. Pachikian BD, Essaghir A, Demoulin JB, Catry E, Neyrinck AM, Dewulf EM, Sohet FM, Portois L, Clerbaux LA, Carpentier YA, Possemiers S, Bommer GT, Cani PD, Delzenne NM. Prebiotic approach alleviates hepatic steatosis: implication of fatty acid oxidative and cholesterol synthesis pathways. Mol Nutr Food Res. 2013 Feb;57(2):347-59. doi: 10.1002/mnfr.201200364.

31. Delgado GT, Tamashiro WM, Maróstica Junior MR, Pastore GM. Yacon (Smallanthus sonchifolius): a functional food. Plant Foods Hum Nutr. 2013 Sep;68(3):222-8. doi: 10.1007/s11130013-0362-0.

32. Valentová K, Lebeda A, Dolezalová I, Jirovský D, Simonovska B, Vovk I, Kosina P, Gasmanová N, Dziechciarková M, Ulrichová J. The biological and chemical variability of yacon. J Agric Food Chem. 2006 Feb 22;54(4):1347-52. PMID: 16478259.

33. Geyer M, Manrique I, Degen L, Beglinger C. Effect of yacon (Smallanthus sonchifolius) on colonic transit time in healthy volunteers. Digestion. 2008;78(1):30-3. doi: 10.1159/000155214.

34. Rajkumar H, Kumar M, Das N, Kumar SN, Challa HR, Nagpal R. Effect of Probiotic Lactobacillus salivarius UBL S22 and Prebiotic Fructo-oligosaccharide on Serum Lipids, Inflammatory Markers, Insulin Sensitivity, and Gut Bacteria in Healthy Young Volunteers: A Randomized Controlled Single-Blind Pilot Study. J Cardiovasc Pharmacol Ther. 2014 Oct 20. pii: 1074248414555004. [Epub ahead of print] PMID: 25331262. 
35. Merino-Aguilar H, Arrieta-Baez D, Jiménez-Estrada M, MagosGuerrero G, Hernández-Bautista RJ, Susunaga-Notario Adel C, Almanza-Pérez JC, Blancas-Flores G, Román-Ramos R, AlarcónAguilar FJ. Effect of fructooligosaccharides fraction from Psacalium decompositum on inflammation and dyslipidemia in rats with fructose-induced obesity. Nutrients. 2014 Jan 29;6(2):591-604. doi: 10.3390/nu6020591.

\section{Aknowledgement}

To Beatriz Ribeiro Ferreira Pucci, Assistant Professor of English Language (UFAM) for her valuable collaboration in the correction of the English version of the manuscript.

\section{Correspondence:}

Prof. Dr. Sergio Botelho Guimarães

Rua Professor Costa Mendes, $1608 / 3^{\circ}$ andar

60430-140 Fortaleza-CE Brasil

Tel.: (55 85)3366-8083

Fax: (55 85)3366-8064

sergiobotelho@terra.com.br

Received: Jan 16, 2015

Review: Mar 19, 2015

Accepted: Apr 18, 2015

Conflict of interest: none

Financial source: none

${ }^{1}$ Research performed at Department of Surgery, Experimental Surgical Research Laboratory (LABCEX), Federal University of Ceara (UFC), Fortaleza-CE, Brazil. 